\title{
RELAÇÃO ENTRE O NÚMERO DE ACIDENTES DE TRÂNSITO E A MACROTEXTURA SUPERFICIAL DAS RODOVIAS PARANAENSES
}

\author{
A. E. da Silva ${ }^{1}$; B. H. Moraes ${ }^{2}$; K. R. Mendes ${ }^{3}$; J. Villena ${ }^{4}$ \\ 1,2,3,4 Universidade Federal do Paraná, Rua Evaristo F. F. da Costa, 418, Jd. das Américas, Curitiba/PR \\ CEP 80050-540 \\ alineeskelsen@gmail.com ${ }^{1}$,bnohmoraes@gmail.com², karinamendesmail@gmail.com³ ${ }^{3}$ joevillena@gmail.com ${ }^{4}$
}

\begin{abstract}
Resumo: A macrotextura dos pavimentos pode ser definida como as asperezas superficiais causadas pelos agregados aparentes. Quanto mais grosseira a macrotextura maior é a capacidade de escoamento superficial da água e maior é a segurança do motorista no controle do veículo quando o mesmo se desloca a altas velocidades e em condiçóes de pista molhada. Desta forma, a melhora da macrotextura do pavimento é uma alternativa para evitar acidentes de trânsito nas rodovias.
\end{abstract}

Palavras-chave: Macrotextura de pavimentos, acidentes de trânsito, ensaio de mancha de areia)

\section{Introduçáo}

Segundo [1], os acidentes de trânsito no Brasil matam cerca de 45 mil hab/ano, sendo que estes acidentes tem um custo de aproximadamente $\mathrm{R} \$ 50$ bilhóes/ano aos cofres públicos. No Estado do Paraná, a média desse custo entre 2005 e 2014 foi de 3.263,46 milhôes por ano, com a taxa de mortalidade média de 30,46 por 100 mil hab. nesse mesmo período [2]. A segurança nas rodovias também está ligada à qualidade da textura superficial dos pavimentos. Em condiçôes de chuva, as superfícies muito lisas permitem o acúmulo de uma lâmina de água sobre o pavimento causando a perda da aderência da borracha dos pneus com o pavimento. Devido à perda de aderência, os veículos podem aquaplanar e causar acidentes. A macrotextura da superfície é responsável pela aderência do pneu com o pavimento, principalmente, em velocidades acima de $50 \mathrm{~km} / \mathrm{h}$ e em condiçóes de pista molhada [3]. O objetivo deste trabalho é analisar a influência da macrotextura dos pavimentos nos acidentes de trânsito em rodovias paranaenses.

\section{Metodologia}

Levantamento de dados dos índices de acidentes em rodovias do Paraná para classificação dos pontos críticos (correlacionando o fluxo de veículos com a quantidade de acidentes), assim definindo quais os tipos de rodovias que serão analisadas; avaliação da macrotextura da superfície do pavimento, a partir do ensaio de mancha de areia (ASTM D965-96) e drenabilidade (ASTM E2380-05); análise dos dados obtidos e correlação com índices de acidentes de trânsito e velocidades das rodovias. 


\section{Resultados esperados/Conclusóes}

Espera-se obter uma correlação entre a macrotextura, velocidade máxima e o número de acidentes nos pontos críticos analisados. Por fim, com os dados obtidos no ensaios uma velocidade máxima poderá ser sugerida para as rodovias.

\section{Referências}

[1] ULBRICH, G. Acidentes de trânsito podem custar mais de R\$ 50bilhóes a sociedade. Curitiba: Jornal Tribuna, 2017. Disponível em: < http://www.tribunapr.com.br/noticias/brasil/acidentes-de-transito-podem-custar-mais-de-r-50bilhoes-sociedade/>Acesso em: 25 out. 2017.

[2] OBSERVATÓRIO NACIONAL DE TRÂNSITO. Gráfico - Acidentes. Disponível em: <http://iris.onsv.org.br/ iris-beta/\#/stats/maps>. Acesso em: 25 out. 2017.

[3] COZER, F. A.; WRUBLACK, T. Análise funcional do pavimento em pontos críticos de acidentes na rodovia PR-483 entre Francisco Beltráo e Ampére (PR). Pato Branco: Ed. UTFPR, 2015. Disponível em:<http://repositorio. roca.utfpr.edu.br/jspui/bitstream/1/4874/1/PB_COECI_2015_1_01.pdf>. Acesso em: 23 out. 2017. 